\title{
The Correspondence Vocal of Proto-Austronesian and Perai Isolect in Wetar, Maluku
}

\author{
Fredy Frits Maunareng ${ }^{1}$, Simon Sabon Ola ${ }^{2}$, Lanny Isabela Dwisyahri Koroh ${ }^{3}$ \\ \{frits.maunareng@gmail.com ${ }^{1}$, sabon.ola@undana.ac.id ${ }^{2}$, lanny.isabela@gmail.com³ \\ ${ }^{123}$ University of Nusa Cendana Kupang, Nusa Tenggara Timur, Indonesia
}

\begin{abstract}
This research deals with the problem of phonemic correspondence vocal of Proto-Austronesian (PAN) and Perai Isolect (PI). The description of vocal correspondence can not be separated from synchronic phonology overview on PI. Therefore, the purpose of the study was to describe vocal PI on one side, and correspondence with PAN on the other side. Phonology description of PI is examined by generative phonology approach, and further it is done by comparative method to reveal the reflection of PAN in PI. The type of data used is oral and written data. The source of oral data was taken from native speaker, meanwhile written data was taken from various relevant sources, especially for PAN data. In analysis used by comparison method and top-down reconstruction deductive. Synchronically, PI has 5 . There are vowels /i/, /u/, /e/, /o/ and / a /. The syllable pattern of PI is VC with maximum vocal replaying rules is VV. Diachronically, PI phonemes are reflected from PAN, both linear and partial. All of vocal PAN are corresponded with PI, except PAN */ə/ which heritance separately.
\end{abstract}

Keywords - Correspondence, vocal, PAN, perai isolect

\section{Introduction}

Perai Isolect (PI) is one of communication media intra ethnic of Perai on Wetar Island in the region of autonomy Maluku Barat Daya region, The Province of Maluku. From the interlanguage kinship, PI is including to the group of Ambon-Timor language specifically on Wetar language sub-family [1], [2]. Certainly, this grouping is different to what Greenberg has informed [3] that the languages in Wetar includes some languages on Timor Island and language on Alor including on one group which call Alor-Timor group. With a lexicostatistic approach it has been proven that PI is part of the Austronesian family. Surely that claim is not enough if it is not accompanied by a reconstruction method, which shows the similarity of form and meaning. Masrukhi [4] in his research about reflex of PAN to Lubu Language he was explained that the kinship of a language can be proven by the reconstruction of the elements of retention, as well as innovation from the protolanguage. In line with that, Athidi [5] in his study which discussed about reflex of PAN on the three protolanguage in Alor found parallels and developments that appeared in the form of a number of phonemes that can be traced back to the initial stages; for example by phonemic correspondence. Furthermore, by quoting Hock's opinion, Athidi [6] in her other paper she wrote that the inheritance elements contained in the 
protolanguage in principle prove the existence of kinship relations between cognate languages which can be studied with comparative historical studies. Based on all of the opinion above, in the study of historical linguistic needed phonological description. In this research focus to the PI vocal. According to Fernandez [7] and Mbete [8] also they are say that the research on language history is deserved to be started or shown the imagery of the phonology elements of the languages which are going to be studied-appeal. Eventhough, lexicostatistic has showed that PI is part of PAN (despite of Greenberg contradiction), there is no research on phonology element of PI specifically. Base on the explanation, this recent study aims to (a) description of PI vocal, and (b) PAN vocal correspondence form of PI. The vocal description of PI examined with generative phonology approach [9], [10]. The distinctive feature is the smallest unit in the generative phonological studies, like phonetic, lexical, and transcription elements formed by combinations and sequences [9]. Distinctive features have phonetic properties because they are made based on articulatory properties (such as coronal, high) or perceptual (such as syllabic, pressurized). Apart from that the distinctive features can explain a reasonable class that has the same phonological properties in sound changes. Therefore, distinctive features are very useful and helpful, especially, in relation to explanations of sound change rules.

\section{Method}

The method in this research is comparison method. This method aims to determine the sound correspondence [11]-[13]. In this study, PAN is considered as the protolanguage and PI as the inheritance language who will comparison. Furthermore in synchronous analysis the matching technique is used [14] and diachronically, reconstruction technique top-down which is done by deduction. Technique top-down reconstruction is the process of tracking the prototype inherited in the current language as a form of reflection from the protolanguage. As an application of the top-down reconstruction technique, steps are taken (1) gathering the cognate words from the comparable language, (2) determining the word of cognate set, (3) determining the list of protophonem and the formulation of rules [15]. The acquisition of data was based on data type so it was sorted by oral data and written data. Oral data was taken from native speaker who selected by using Swadesh and Hole list, meanwhile written data was taken from various relevant sources, especially for PAN data, it was taken from the writing collection of Wurm and Wilson [16]. The results of the analysis are presented formally and informally [14].

\section{Result and Discussion}

\subsection{The Vocal Description of PI}

1. Vocal Segment

Vocal segment of PI consist of five, they are i/, /u/, /e/, /o/, and /a/; which are completely distribute.

Table 1 Map of PI Vocal

\begin{tabular}{|c|c|c|c|c|}
\hline Tongue & osition & Front Not round & Middle Not round & Back Round \\
\hline High & $\begin{array}{l}\text { Tense } \\
\text { Slack }\end{array}$ & $\begin{array}{c}/ \mathrm{i} /[\mathrm{i}] \\
{[\mathrm{I}]}\end{array}$ & & $\begin{array}{c}/ \mathrm{u} /[\mathrm{u}] \\
{[\mathrm{J}]}\end{array}$ \\
\hline
\end{tabular}




\begin{tabular}{ccccc}
\hline \multicolumn{2}{c}{ Tongue Position } & Front Not round & Middle Not round & Back Round \\
\hline Medium & Tense & $/ \mathrm{e} /[\mathrm{e}]$ & & $/ \mathrm{o} /[\mathrm{o}]$ \\
& Slack & {$[\varepsilon]$} & & {$[\mathrm{o}]$} \\
Low & Slack & & $/ \mathrm{a} /[\mathrm{a}]$ & \\
\hline
\end{tabular}

The five vocal above showed the relaxation mechanism which pictured as follow

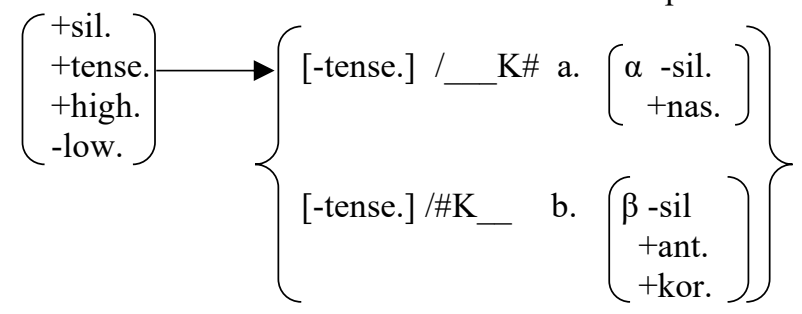

The phonology rules above can be read as vocal which characteristic [+sil.], [+tense.] will commit relaxation, if (a) that vocal is followed by nasal consonant; and (b) locate in open syllable that follow the consonant beside dons-velar consonant.

2. Positive Conditions

Canonic morpheme pattern of PI origin is formulated as follow.

$$
\left\{\begin{array}{l}
\mathrm{V} \\
((\mathrm{K})(\mathrm{V}))
\end{array}\right\} \mathrm{V} \quad\left((\mathrm{KV})^{\mathrm{R}}((\mathrm{K}) \mathrm{V})^{\mathrm{R}}\right)
$$

The formulation above tells:

a) An origin morpheme is contain $\mathrm{V}$ segment ([+sil.]) at least;

b) The consonant series which is the most maximal in origin morpheme is $\mathrm{K}$ ([-sil.]);

c) The vocal series which is the most maximal in origin morpheme is $\mathrm{VV}([+$ sil. $]$ [+sil.]);

d) An origin morpheme can be ended and began with $\mathrm{K}([+$ sil.]).

\subsection{The Description Of Pan-Pi Correspondence}

1. Vocal Correspondence

PAN */i/ $\left(*_{\mathrm{i}-}, *_{-\mathrm{i}-}, *_{-\mathrm{i}}\right) \approx \mathrm{PI} / \mathrm{i} /(\mathrm{i}-,-\mathrm{i}-,-\mathrm{i})$

Example:

$\begin{array}{lll}\text { PAN } & \text { PI } & \text { Glos } \\ \text { *ina } & \text { ina } & \text { 'mother' } \\ \text { *uliq } & \text { falik } & \text { 'return' } \\ \text { *lima } & \text { lima } & \text { 'five' } \\ \text { *paRi } & \text { ari } & \text { 'stingray' }\end{array}$

The data above shows the proto-phoneme of PAN */i/ corresponded with the $/ \mathrm{i} /$ on PI. This correspondence also suggests that proto-phoneme of PAN */i/, both in penultimate position $(* \mathrm{i}$ ) and or ultimate $(*-i)$, both are still show the original and linearly arranged.

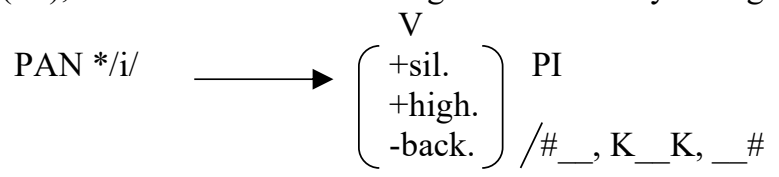


That function above means to express the PAN */i/ correspondences with PI vocal $/ \mathrm{i} / \mathrm{which}$ has feature ([+sil.], [+high.], [-back.]) in all position like initial position, inter-consonant and also final position.

$\mathrm{PAN} * / \mathrm{u} /\left(* \mathrm{u}-,{ }^{*}-\mathrm{u}-,{ }^{*}-\mathrm{u}\right) \approx \mathrm{PI} / \mathrm{u} /(\mathrm{u}-,-\mathrm{u}-,-\mathrm{u})$.

Example:

$\begin{array}{lll}\text { PAN } & \text { PI } & \text { Glos } \\ \text { *uRat } & \text { uak } & \text { 'sinew' } \\ \text { *bulu } & \text { fulung } & \text { 'hair' }\end{array}$

*pitu itu 'seven'

The data above shows the proto-phoneme of PAN */u/ correspondences with $/ \mathrm{u} /$ on PI, either as nucleus in penultimate position $\left({ }^{*} \mathrm{u}-\right)$ take for example *uRat $>u a k$ 'sinew', and also ultimate $\left(*_{-u}\right)$ take for example on etymon *susu > susu 'milk'.

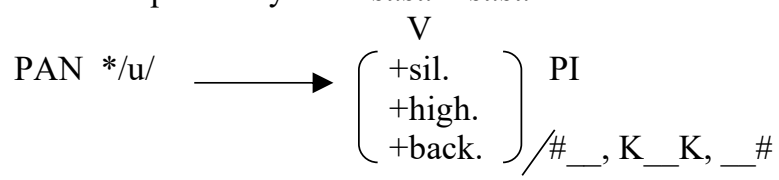

The function above suggests that PAN vocal */u/ arranged linearly on PI becoming vocal /u/ which has characteristic ([+sil.], [+high.], [+back.]) in all position like initial position, interconsonant and also final position.

Besides that, the very limited data also shows the PAN vocal innovation */u/ $>$ PI /a/, take for example on etymon *uliq $>$ falik 'return', *tungu $>$ taha 'wait'. Because of that innovation, it is confirm that PAN */u/ separately arranged to becoming PI $/ \mathrm{u} /, / \mathrm{a} /$ as the formulation.

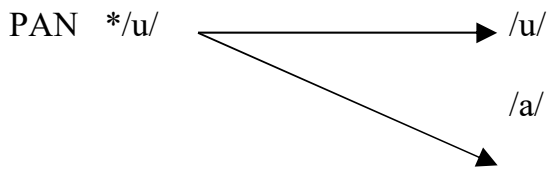

There is a split tendency PAN */u/ > PI /a/ if it is followed by consonant which characters like [+son.], [+voice.], and or it is follow the consonant with character like [+cor.], [+ant.].

$\mathrm{PAN} * /$ /(*ə-, *-ə-) $\approx \mathrm{PI} / \varnothing-/, /-\mathrm{e}-/$

Example:

$\begin{array}{lll}\text { PAN } & \text { PI } & \text { Glos } \\ \text { *əpat } & a k & \text { 'four' } \\ \text { *təbu } & \text { tefu } & \text { 'cane' } \\ \text { *Dəpa } & \text { rea } & \text { 'fathom' } \\ \text { *təluR } & \text { telur } & \text { 'egg' }\end{array}$

By looking at the data above, PAN */ə/ on penultimate position which followed by slow consonant unseen bilabial [p] is correspondence with the zero phoneme /ø/ on PI. Meanwhile, on medial position, PAN */a/ it is correspondence with the /e/ on PI. 


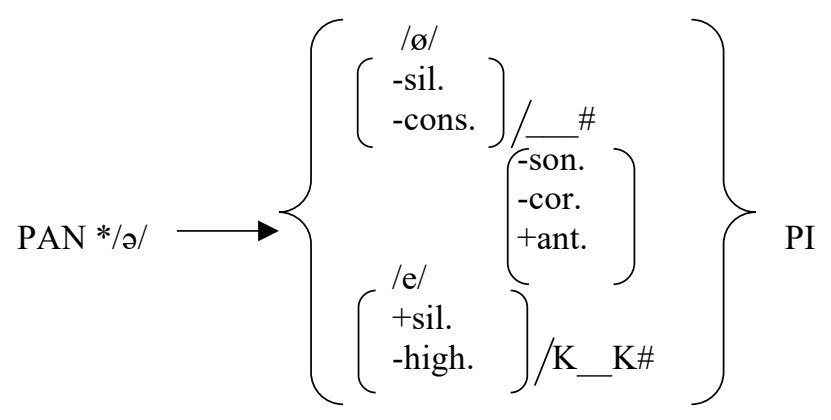

The function above signifies that the PAN */o/ which is locate in initial position of a morpheme will be subsided on PI if it is followed by consonant which character [-son.], [-cor.], [+ant.] / $\mathrm{p} /$ and will becoming /e/ if it is located in inter-consonant position.

Besides the above regularity, there is also limited data which show the changing of PAN */ə/ > PI /a/, /i/. Take for example, *əsa > hasa 'one', *əmpu > apu 'grandmother', *barəq > para 'swollen', *boniq > fini 'seed'. The reflection happens sporadically, which generally can be figure as follow.

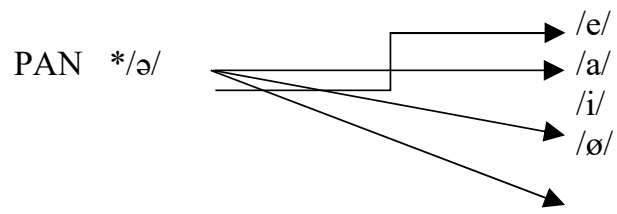

PI

The function above signifies that the reflection of PAN vocal */ə/ territory orderly to becoming /e/, /a/, /i/ and /ø/ on PI. The changing happens sporadically.

$\mathrm{PAN} * / \mathrm{a} /\left(*_{\mathrm{a}-}, *_{-} \mathrm{a}-, *_{-\mathrm{a}}\right) \approx \mathrm{PI} / \mathrm{a} /(\mathrm{a}-,-\mathrm{a}-,-\mathrm{a})$

Example:

$\begin{array}{lll}\text { PAN } & \text { PI } & \text { Glos } \\ \text { *anak } & \text { ana } & \text { 'child' } \\ \text { *mata } & \text { mata } & \text { 'eye' } \\ \text { *lima } & \text { lima } & \text { 'hand' }\end{array}$

It is seem on the data above, the proto-phoneme PAN of */a/ correspondences with the /a/ on PI, either it is as nucleus on penultimate position $\left(*^{*}-\right)$ and or penultimate $\left(*_{-a}\right)$ as it is seem on $\mathrm{KF}$ as follow.

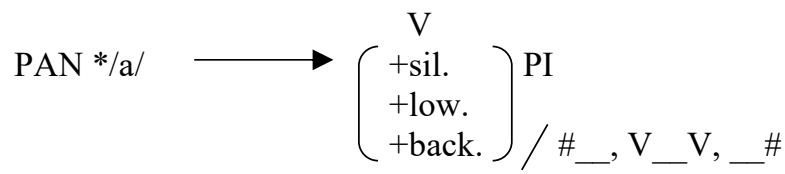

The function above signifies that the vocal PAN of */a/ linearly heredities on PI to becoming vocal /a/ which has characteristic ([+sil.], [+low.], [+back.]), either in penultimate position (*a- $>$ a-, $*-a->-a-)$ and or ultimate $(*-a>-a)$.

Besides the regularly reflection as on the function shows above, the PAN */a/ also reflects split-ly on PI to becoming /e/ and /o/, take for example *basaq > pehe 'wet', *matzy > mete 'dead', *gaga > gegay 'silent', *taun > ton 'year', *Daun > roy 'leaf'. The formulation of PAN $* / a /$ can be seen as follow. 


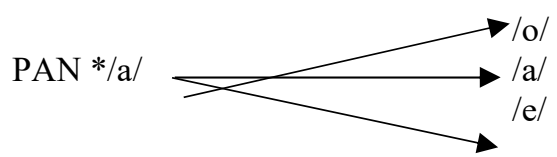

PI

The heredity function above means to express that the PAN */a/ heredities separately on PI as /a/, /e/ dan /o/. The reflection of PAN vocal of $* / a />$ PI /e/ on the inter-consonant position still be able to be explained as the dissimilation process, some of the other is the heredity process which happen sporadically that isn't able to be explained with the heredity function.

Based on the descriptions above, the overall PAN and IP vocal correspondence can be seen in the table below

Table 2 The overall of PAN and IP vocal correspondence

\begin{tabular}{|c|c|c|c|c|c|}
\hline PAN & PI & \multicolumn{3}{|c|}{ Distribution } & Remarks \\
\hline \multirow{4}{*}{$\begin{array}{l}*_{\mathrm{i}} \\
*_{\mathrm{u}}\end{array}$} & /i/ & i- & $-\mathrm{i}-$ & $-\mathrm{i}$ & Retention \\
\hline & $/ \mathrm{u} /$ & $\mathrm{u}-$ & $-\mathrm{u}-$ & $-\mathrm{u}$ & Retention \\
\hline & /a/ & & $-a-$ & $-a$ & $\begin{array}{c}\text { If in the middle and followed by consonant with the } \\
\text { characteristic }[+ \text { son. }],[+ \text { voice. }]\end{array}$ \\
\hline & & & & & $\begin{array}{l}\text { If in the final and followed consonant with the characteristic } \\
\qquad[+ \text { cor. }],[+ \text { ant. }]\end{array}$ \\
\hline \multirow{4}{*}{$*_{\partial}$} & /e/ & & & & Innovation, if it are in the position between consonants \\
\hline & /i/ & & $-\mathrm{i}-$ & & Innovation, sporadic \\
\hline & $/ \mathrm{a} /$ & $a-$ & $-a-$ & & Innovation, sporadic \\
\hline & $/ \varnothing /$ & $\varnothing-$ & & & If in the initial position \\
\hline \multirow[t]{3}{*}{$* a$} & $/ \mathrm{a} /$ & $a-$ & $-a-$ & $-a$ & Retention \\
\hline & /e/ & & $-e-$ & & Innovation, sporadic \\
\hline & /o/ & & $-0-$ & & Innovation, sporadic \\
\hline
\end{tabular}

\section{Conclusion}

In this study, the researcher synchronically shows 5 vocal segments. Those vocal segments are: $/ i /, / u /, / e /, / o /$ and $/ a /$. From the five vocal segments, there are four vocals which shows the relaxation mechanism, they are $/ \mathrm{i} />[\mathrm{I}]$ vocal if it is followed by nasal consonant $/ \mathrm{u} />[\mathrm{v}]$ vocal if it is followed by nasal consonant; /e/ $>[\varepsilon]$ vocal if it is on open position and it is not followed by dorsovelar consonant and $/ 0 />[0]$ vocal if it is on open position. The syllable pattern of PI is VK with replaying function maximal is VV. Diachronically, the vocal PI $<$ vocal PAN which reflects linearly, except PAN */ə/ reflects separately by not maintaining its authenticity. I hope that this paper can inspire the linguist to steal a glance to Perai Isolect and other languages in Wetar-the enclave area of NKRI-RDTL-deeper and further from various perspectives.

\section{References}

[1] M. Taber, "Toward A Better Understanding Of The Indigenous Languages Of Southwestern Maluku," Ocean. Linguist., vol. 32, no. 3, p. 389-441, 1993.

[2] F. F. Maunareng, "Kajian Leksikostatistik terhadap Isolek-isolek di Wetar dan Kisar," in In Simon Sabon Ola \& Laurens Kian Bera-Proceedings of The National Seminar in The Retirement of Prof. Dr. A. M. Mandaru, M.Pd. Pg, 2013, p. 152-174. 
[3] I. Y. Fernandez, "Inventarisasi Bahasa-bahasa Daerah di Propinsi Nusa Tenggara Timur," Humaniora, vol. 19, no. 3, p. 241-247, 2007.

[4] M. Masrukhi, "Refleksi Fonologis Protobahasa Austronesia (PAN) pada Bahasa Lubu (BL)," Humaniora, vol. 14, no. 1, p. 86-93, 2002.

[5] I. A. I. Adhiti, "Pantulan (Refleks) Proto Austronesia (PAN) Ke Protobahasa Kabola, Protobahasa Hamap, Dan Protobahasa Klon Di Pulau Alor, Nusa Tenggara Timur," Kulturist. J. Bhs. dan Budaya, vol. 1, no. 1, 2017.

[6] I. A. I. Adhiti, "Kajian Linguistik Historis Komparatif pada Pola Perubahan Bunyi," Kulturist. J. Bhs. dan Budaya, vol. 3, no. 2, 2019.

[7] I. Y. Fernandez, Relasi Historis Kekerabatan Bahasa Flores. Kajian Linguistik Komparatif Terhadap Sembilan Bahasa di Flores. Ende: Nusa Indah, 1996.

[8] A. M. Mbete, Metode Linguistik Diakronis. Denpasar: Udayana University Press, 2002.

[9] S. A. Schane, Fonologi Generatif. (Interpreter by Kuntjanawati Gunawan). Jakarta: Summer Institute of Linguistics, 1992.

[10] J. T. Jensen, Principles of Generative Phonology, An Introduction. Amsterdam: Benjamin Publishing Company, 2004.

[11] R. A. Sholihah, "Korespondensi Fonemis Bahasa Melayu Makassar, Bahasa Mandar dan Bahasa Bugis," Gramatika J. Ilm. Kebahasaan dan Kesastraan, vol. 3, no. 1, pp. 60-75, 2015.

[12] T. Crowley, An Introduction to Historical Linguistics. Papua New Guinea: Universitas of Papua New Guinea, 1987.

[13] L. Bloomfield, Bahasa (Interpreter I). Jakarta: Gramedia Pustaka Utama, 1995.

[14] Sudaryanto, Metode dan Aneka Teknik Analisis Bahasa. Yogyakarta: Duta Wacana University Press, 1993.

[15] Sudirman, "Refleksi Proto-Austornesia pada Bahasa Lampung," LITERA J. Penelit. Bahasa, Sastra dan Pengajarannya, vol. 4, no. 2, pp. 221-234, 2005.

[16] S. A. Wurm and B. Wilson, English Finderlist Of Reconstructions In Austronesian Languages. Australia: Department Of Linguistics Research School Of Pacific Studies The Australian National University, 1978. 